Percy Bysshe Shelley 
Other Paperbacks in the Griffin Authors Series

GEOFFREY CHAUCER Edwin J. Howard ANDRE GIDE Thomas Cordle THOMAS HARDY Richard Carpenter HAROLD PINTER Arnold P. Hinchliffe D. H. LAWRENCE RonaldP.Draper 


\section{Percy Bysshe Shelley}

\section{By DONALD H. REIMAN}

The Carl H. Pforzheimer Library 
ISBN 978-0-333-19653-3 ISBN 978-1-349-02954-9 (eBook)

DOI 10.1007/978-1-349-02954-9

(C) Twayne Publishers, Inc., 1969

Reprint of the original edition 1969

All rights reserved. No part of this publication may be reproduced or transmitted, in any form or by any means, without permission

First published 1976 by

THE MACMILLAN PRESS LTD

London and Basingstoke

Associated companies in New York Dublin

Melbourne Johannesburg and Madras

SBN 333196538

This book is sold subject to the standard conditions of the Net Book Agreement.

The paperback edition of this book is sold subject to the condition that it shall not, by way of trade or otherwise, be lent, resold, hired out, or otherwise circulated without the publisher's prior consent, in any form of binding or cover other than that in which it is published and without a similar condition including this condition being imposed on the subsequent purchaser. 
For My Parents, Mildred and Henry W. Reiman 


\section{Preface}

In this book I have tried to give a brief, clear, and accurate account of Shelley's life, freshly examining existing accounts in the light of the primary evidence upon which they are based. I have studied Shelley's writings anew and have given inclusive readings of as many of them as space permits-especially those poems and essays that are, in my opinion, most important for a comprehension of his thought and art. One wishing to understand Shelley should read at least these works: Alastor, "Mont Blanc," "Hymn to Intellectual Beauty," "Lines written among the Euganean Hills," "Julian and Maddalo," Prometheus Unbound, The Cenci, "A Defence of Poetry," Epipsychidion, Adonais, and "The Triumph of Life." I have outlined the structure of each of them in detail, hoping to guide the reader's understanding of the whole work (and the relation of individual parts to the whole) by charting its thematic development. In treating such less-read works as The Revolt of Islam, "Peter Bell the Third," "The Witch of Atlas," and Hellas, I have condensed the thematic analysis but have quoted key passages to give the reader the flavor of poems for which he may not find time during his initial study of Shelley.

The chronological plan of the book is not only the most convenient for the reader wishing to review a phase of Shelley's career; it is, I believe, truest to the essential growth of Shelley as an artist. Some have denied that his thought developed, but an examination of his changing conception of the roles of love and poetry in human life shows how fallacious this denial is. Shelley's goals remained essentially unaltered, but his views on how and to what extent men might achieve these ideals were tempered through an eventful lifetime of testing ideas in the fires of experience. Thus, although Shelley is not essentially an autobiographical poet, an understanding of his life aids one in accounting for certain shifts of emphasis in his poetry. 
I accept, of course, full responsibility for the interpretations presented here (a number of which depart from previous readings), but I am greatly indebted to numerous scholars and critics who have written on Shelley. Allusions in the text, as well as in the notes and bibliography, both acknowledge my specific debts and, hopefully, will guide the interested reader from this necessarily brief introduction to more detailed secondary studies and to the primary materials on which they are based. I have usually quoted (and cited locations) of Shelley's published writings from the following editions: poetry from the Oxford Standard Authors edition, ed. Thomas Hutchinson (cited as "OSA"); prose from The Complete Works of Percy Bysshe Shelley, ed. Roger Ingpen and Walter E. Peck (Julian Edition; cited as "Julian"); letters from The Letters of Percy Bysshe Shelley, ed. Frederick L. Jones (cited as "Letters").

I am grateful to Indiana University Press for permission to quote from Dante, La Vita Nuova, A New Translation by Mark Musa (Bloomington, 1962). I wish to thank Duke University and the University of Wisconsin-Milwaukee for generously supporting my research; Miss Evelyn Johnson for faithful work as my student assistant at the University of Wisconsin-Milwaukee; my students at Duke, University of Illinois, and University of Wisconsin-Milwaukee for giving their best and demanding mine; The Carl and Lily Pforzheimer Foundation, Inc., and its president, Mr. Carl H. Pforzheimer, Jr., for a three-month fellowship in the summer of 1965; Miss Doucet Devin for typing early drafts of several chapters; Professor Kenneth Neill Cameron for sharing with me his unsurpassed knowledge of the materials of research in Shelley's life and times; Professor Jack Stillinger for giving the manuscript the benefit of his exceptional critical intelligence; and Mary Warner Reiman for her partnership in every stage of this work.

New York

Donald H. Remman 


\section{Contents}

\section{Preface}

Chronology

1. A World to Reform 15

2. Student to Poets 33

3. A Hermit at Marlow 47

4. Green Isles 62

5. Roman Scenes 74

6. The Chameleon 95

7. Built Beyond the Grave 121

8. Eyeless Charioteer 142

Notes and References 163

Selected Bibliography 173

$\begin{array}{ll}\text { Index } & 179\end{array}$ 


\section{Chronology}

1792 Percy Bysshe Shelley born August 4 at Field Place, near Horsham, Sussex.

1798 Studies with his clergyman, the Reverend Evan Edwards. 1802- Attends Syon House Academy at Isleworth, near London. 1804

1804- At Eton.

1810

1808 Begins corresponding with his cousin Harriet Grove (their "engagement" ends in 1810).

1810 Zastrozzi published (spring). Original Poetry by Victor and Cazire published and withdrawn (autumn). Enters University College, Oxford, and meets Thomas Jefferson Hogg (Oct.). Posthumous Fragments of Margaret Nicholson published (Nov.). St. Irvyne published (Dec.).

1811 Meets Harriet Westbrook (Jan.). The Necessity of Atheism published (Feb.). Expelled with Hogg from Oxford (March 25). Elopes with Harriet Westbrook; married in Edinburgh on Aug. 29. At York, Hogg tries to seduce Harriet; the Shelleys move to Keswick.

1812 Political activities in Dublin. Address to the Irish People and Proposals for an Association ... published (Feb.). Declaration of Rights printed. Returns to Wales (April 6); moves to Lynmouth, Devon; writes Letter to Lord Ellenborough. Joined by Elizabeth Hitchener in July (she leaves in Nov.). Goes to North Wales (Sept.). Meets Godwin in London (Oct.).

1813 Flees Tremadoc, Wales (Feb. 27); goes to Ireland. Returns to London (April 5). Queen Mab issued (May). Ianthe Shelley born (June 23). Settles at Bracknell (July).

1814 A Refutation of Deism printed. Elopes with Mary Wollstonecraft Godwin (July 27). They (with Jane "Claire" 
Clairmont) tour the Continent, returning Sept. 13. First son, Charles, born to Harriet (Nov. 30).

1815 Sir Bysshe Shelley dies (Jan. 5). Mary's first child born (Feb. 22; dies two weeks later). In June, Shelley begins to receive annual income $£ 1000$ ( $\& 200$ paid directly to Harriet). Moves to cottage near Bishopsgate (Aug.).

1816 William Shelley born (Jan. 24). Alastor published (Feb.). Visits the Continent; lives near Byron; writes "Hymn to Intellectual Beauty" and "Mont Blanc" (May-Aug.). Returns to England (Sept. 8). Fanny Imlay's suicide (Oct. 9). Harriet Shelley drowns herself (Nov. 9; discovered Dec. 10). Marries Mary (Dec. 30).

1817 Allegra, Claire's daughter by Byron, born (Jan. 12). Denied custody of Ianthe and Charles (March 27). Settles at Marlow (March). Proposal for Putting Reform to the Vote published (March). Finishes Laon and Cythna and begins Rosalind and Helen (Sept.). Clara Shelley born (Sept. 2). History of a Six Weeks' Tour published. Writes Address .... on the Death of the Princess Charlotte (Nov.). Laon and Cythna published and withdrawn (Dec.); reissued as The Revolt of Islam (Jan., 1818).

1818 Sails to Continent (March 11). Sends Allegra to Byron (April 28). At Baths of Lucca completes Rosalind and Helen (July; published spring 1819). Goes to Venice with Claire; Mary follows with children (Aug.-Sept.). Clara Shelley dies (Sept. 24). At Este, composes most of "Julian and Maddalo," "Euganean Hills," Prometheus Unbound, Act I. Visits Rome; settles at Naples (Dec.).

1819 Leaves Naples (Feb. 28). Writes Acts II-III of Prometheus in Rome (March-April). William Shelley dies (June 7). Moves to Leghorn; writes The Cenci (summer; published spring 1820) and Mask of Anarchy (Sept.). Moves to Florence (Oct. 2); son Percy Florence born (Nov. 12). Writes "Peter Bell the Third," "West Wind," and "Philosophical View of Reform"; finishes Prometheus Unbound (published Aug., 1820).

1820 Moves to Pisa (Jan. 26); writes "Sensitive Plant" (March). At Leghorn (June-Aug.) writes "Ode to Liberty," "Skylark," "Letter to Maria Gisborne." At Baths at San Giuliano (Aug.-Oct.) writes "Witch of Atlas," "Ode to Naples," 
Swellfoot the Tyrant (published and suppressed, Dec.). Returns to Pisa (Oct. 31).

1821 Visits Teresa Viviani; writes Epipsychidion (Jan.-Feb.; published anonymously, May). Meets Edward and Jane Williams (Jan. 13). Writes "A Defence of Poetry" (Feb.March). News of Keats's death (Rome, Feb. 23) arrives from Horace Smith on April 11. Writes Adonais (MayJune; printed July). Visits Byron at Ravenna (Aug.) and persuades him to live at Pisa (arrives Nov. 1). Writes Hellas (Oct.; published Feb., 1822).

1822 Works on "Charles the First." Trelawny arrives (Jan. 14). Writes poems to Jane (Jan. ff.). Allegra Byron dies (April 20). Shelleys and Williamses move to San Terenzo (April 30). Receives the Don Juan, his boat (May 12). Writes "Triumph of Life" (May-June). Sails to Leghorn (July 1) and drowns on return voyage (July 8 ). 